\title{
IMPLEMENTASI SOFTWARE AXATA POS DALAM MEMENUHI KEBUTUHAN SISTEM INFORMASI AKUNTANSI PADA KLINIK KESEHATAN DITINJAU DARI PERSPEKTIF MANAJEMEN BISNIS SYARIAH
}

\author{
AXATAPOS SOFTWARE IMPLEMENTATION IN MEETING THE \\ NEED FOR ACCOUNTING INFORMATION SYSTEMS IN THE HEALTH \\ CLINIC VIEWED FROM THE PRESPECTIVE OF SHARIA BUSINESS \\ MANAGEMENT
}

\author{
Bagas Noval Pradipta, Lantip Susilowati \\ Fakultas Ekonomi dan Bisnis Islam IAIN Tulungagung \\ Jl. Mayor Sujadi No.46, Kedung Waru, Jawa Timur \\ E-mail: bgs.noval97@gmail.com, lantip_susilowati@yahoo.co.id
}

Husnul Haq

Departement Fiqh and Ushul Fiqh International Islamic University Malaysia

Kuala Lumpur Malaysia

h.husnul@live.iium.edu.my

Naskah diterima 20 Juli 2020, di-review 07 September 2020, disetujui 31 Desember 2020

\begin{abstract}
Health is one of the important things in life. Health service is the most important necessary, along with increasing public awareness of the importance of health. Sima Husada Clinic is a health clinic which is focused on outpatients and inpatients, in which the data processing transaction used is a manual system. In this research, the researcher will elaborate in outline about accounting information by using software AxataPOS. The aim of this research is to describe accounting program facilitiy, in order to simplify entering data transaction and organizing financial report. The research method of this study were descriptive research. In collecting the data, the researcher used observation directly about daily transaction, beside that the researcher also did interview with the manager and Administration. The result of this research showed that the implementation of software AxataPOS to Sima Husada Clinic can be applied since it eases the clinic in processing the data of financial transaction for instance recording the cash out and cash in, payroll, medical stock such as the outcoming item, the incoming item and stock opname, and in the perspective of sharia business management a system is very much needed to make it easier to achieve the benefit of society. In this case, automatically it will generate the financial report which is needed without a long stage.
\end{abstract}

Keywords: The Implementation of Software, Accounting Information System, Sharia Business Management, Health Clinic, AxataPos

Abstrak: Kesehatan merupakan salah satu bagian yang penting. Jasa pelayanan kesehatan salah
satu kebutuhan yang sangat penting, seiring dengan meningkatnya kesadaran masyarakat terhadap
pentingnya arti kesehatan. Klinik Sima Husada merupakan klinik yang bergerak di bidang kesehatan
yang berfokus pada pasien rawat jalan dan rawat inap, di mana proses pengolahan data transaksi
masih menggunakan sistem manual. Dengan penelitian ini peneliti menjabarkan secara garis besar
mengenai informasi akuntansi menggunakan software AxataPOS. Tujuan dari penelitian ini adalah
untuk mendiskripsikan fasilitas berupa program akuntansi agar memudahkan dalam pengentrian 
data transaksi dan penyusunan laporan keuangan. Metode penelitian yang digunakan dalam penelitian ini yaitu metode penelitian deskriptif dimana pengumpulan data yang digunakan adalah pengamatan secara langsung terhadap transaksi yang dilakukan sehari-hari, selain itu melakukan wawancara kepada Manager dan Admin. Hasil penelitian ini menyatakan bahwa implementasi software AxataPos bagi Klinik Sima Husada dapat di terapkan, hal ini sangat memudahkan klinik dalam pengolahan data transaksi keuangan seperti pencatatan kas keluar, kas masuk, penggajian dan persediaan obat obatan seperti barang keluar, barang masuk, dan stock opname, serta dalam prespektif manajemen bisnis syariah sebuah sistem sangat diperlukan guna mempermudah dalam mencapai kemaslahatan masyarakat. Dengan hal ini maka secara otomatis akan menghasilkan laporan keuangan yang dibutuhkan tanpa melalui tahapan-tahapan yang panjang.

Kata Kunci: Implementasi Software, Sistem Informasi Akuntansi, Manejemen Bisnis Syariah, Klinik Kesehatan, AxataPos.

\section{PENDAHULUAN}

$P_{1}$ erkembangan bisnis syariah di Indonesia kini mulai berkembang. Adapun faktor pendorongnya yaitu sebagian besar masyarakat Indonesia adalah muslim, dimana dalam pemanfaatan produk maupun penggunaanya harus halāl dan tayyib. Selain itu ada beberapa prinsip bisnis syariah yang tidak boleh terabaikan diantaranya: dilarang menerapkan cara yang menimbulkan kebathilan dan merusak, dilarang menerapkan unsur perjudian dalam proses bisnisnya, tidak saling menzalimi (merugikan) satu sama lain, dilarang curang dalam penentuan timbangan, takaran atau pemalsuan kualitas, dan dilarang menerapkan bisnis dengan unsur riba atau sistem bunga (Choirul Huda, 2016:166).

Pertumbuhan ekonomi suatu negara sebagaimana yang kita ketahui merupakan suatu hal yang harus diperhatikan, karena disetiap negara pada dasarnya ingin menjadi lebih baik kedepannya. Dengan pemanfaatan teknologi yang semakin berkembang pertumbuhan ekonomi tersebut secara tidak langsung menyesuaikan dengan teknologi sesuai kebutuhan penggunaannya (Hermaya Ompusunggu, 2018:2). Demikian yang dilakukan oleh klinik. kesehatan merupakan termasuk satuan bagian yang terpenting. Bidang ini memiliki tujuan untuk meningkatkan kualitas kesehatan masyarakat, dengan memfasilitasi pelayanan kesehatan yang lebih merata dan bisa terjangkau oleh masyarakat perkotaan maupun perdesaan (Dana Ika, 2016:1).

Dengan adanya manajemen yang baik maka akan menciptakan kualitas kegiatan bisnis yang baik terutama di jasa pelayanan kesehatan. Jasa pelayanan kesehatan termasuk kebutuhan yang sangat penting, seiring dengan perkembangan waktu yang disertai kesadaran masyarakat terhadap pentingnya arti kesehatan. Maka ada sebuah lembaga yang dapat menangani masalah kesehatan yaitu lembaga yang disebut klinik. Dengan hal ini klinik harus menunjang kualitas pelayanan kesehatan dan sumber daya yang memadai baik dari segi sumber daya manusia, modal, dan teknologi yang digunakan untuk kelangsungan operasionalnya. Sehingga proses operasionalnya sejalan dengan tujuan dari bisnis syariah, yaitu untuk kemaslahatan masyarakat.

Klinik Sima Husada merupakan klinik kesehatan yang dikelola oleh kepemilikan tunggal, dimana usaha ini dijalankan sendiri oleh perorangan tanpa menggunakan bentuk usaha yang terpisah dan tersendiri, Semua hak yang dimiliki 
usaha tersebut merupakan hak yang dimiliki oleh si pemilik. Demikian pula, semua kewajiban atau hutang yang ditanggung oleh usaha tersebut secara hukum merupakan kewajiban atau hutang dari si pemilik (Akram Khan, 2008:173). Klinik ini berfokus pada pasien rawat jalan dan rawat inap, selian itu juga tersedia apotek untuk memenuhi kebutuhan obat-obatan bagi pasien klinik tersebut. Bahkan di apotek tersebut juga menyediakan obat terlarang yang berjenis pskotropik dan narkotik, dimana obat-obatan terssebut tentunya memiliki pengawasan khusus dan tidak sembarangan dapat digunakan di semua pasien, hanya pasien dengan kondisi tertentu yang dapat menggunkan obat tersebut, bentuk pengawasannya adalah dengan Sistem Pelaporan Narkotika dan Psikotropika (SIPNAP) dimana pelaporan obat tersebut diberikan kepada pasien yang memiliki ke jelasan kemudian di laporkan ke dinas kesehatan setiap bulannya.

Akan tetapi hal ini bertolak belakang dengan konsep manjemen bisnis syariah, dimana dalam konsep syariah tersebut tidak diperbolehkan menjual barang yang dikatagorikan haram seperti psikotropik dan narkotika. Namum dengan adanya pengawasan secara jelas, dan ada manfaat yang diberikan, maka hal ini diperbolehkan menurut pandangan islam. Sebelumnya klinik ini menggunakan metode hybrid dalam pencatatan transkasi, yaitu dengan software lama yang hanya digunakan untuk mengentri jasa, dan obat-obatan ketika pasien menebus obatnya, dan menggunakan pencatatan di buku khusus untuk mengontrol persediaan obat-obatan, kas keluar, gaji pegawai, dan komisi pegawai yang ada di klinik tersebut. Jadi ketersediaan sitem informasi akuntansi bisa di katakan belum ada secara spesifik.

Menurut UU no 44 tahun 2009 tentang Rumah Sakit, pasien merupakan orang yang membutuhkan konsultasi kesehatan untuk mendapatkan jasa pelayanan kesehatan di rumah sakit baik secara langsung maupun tidak langsung. Bentuk pelayanan kesehatan yang diberikan oleh Klinik Sima Husada bagi pasiennya adalah rawat inap dan rawat jalan. Pelayanan rawat jalan dimulai dari proses registrasi rawat jalan, pemeriksaan pasien oleh dokter atau perawat, kemudian pemberian resep dari dokter dan pengambilan obat oleh pasien di apotek Klinik Sima Husada, serta diakhiri dengan penebusan biaya obat dan rawat jalan tersebut. Sedangkan pelayanan rawat inap dimulai dari proses registrasi, pemeriksaan dokter atau perawat yang mana pasien tersebut memerlukan perawatan intensif atau observasi ketat karena penyakitnya sampai dalam kondisi sembuh atau baik, dan kemudian diakhiri penebusan biaya obat dan rawat inap (Patricia Mamahit, 2014:540).

Dalam peraturan Menteri Kesehatan Republik Indonesia No. 028/Menkes/PER/I/2011 pasal 1 ayat 1 klinik adalah sebuah fasilitas pelayanan kesehatan yang mengadakan pelayanan kesehatan per individual serta menyediakan pelayanan medis dasar dan/atau spesialistik, dengan dipimpin oleh satu tenaga medis yang beranggotakan beberapa jenis tenaga kesehatan. Pada dasarnya Islam memperbolehkan mengimplementasi teknologi yang diharapkan dapat mempermudah dan memberikan kemaslahatan terhadap orang banyak.

Implementasi Software Axata Pos \|135 
Klinik memerlukan sebuah sistem informasi pengolahan data yang mendukungnya agar pelaksanaan operasionalnya agar lebih cepat dan tepat. Dengan adanya sistem informasi akuntansi diharapkan adanya peningkatan efetivitas dan efesiensi kerja yang hasil akhirnya dapat meningkatkan pengendalian internal terhadap pemasukan klinik. Sistem informasi akuntansi dapat melakukannya dengan manual maupun sistem terkomputerisasi. Hal ini juga menjadi dasar yang sangat penting dalam organisasi untuk mengubah cara pengambilan, pemrosesan, penyimpanan dan pendistribusian informasi. Dengan ini, teknologi informasi secara terus menerus mengalami peningkatan penggunaan dalam sistem informasi akuntansi. Organisasi haruslah memposisikan sistem di bagian terdepan, dan mempertimbangkannya dalam segi sistem maupun sumber daya manusia sebagai seseorang pengendali sistem informasi akuntansi yang ada. Sistem pengendalian internal yang digunakan akan sangat berguna kedepannya dalam mencegah atau mengamankan jika terjadi kesalahan dan kecurangan yang tidak diinginkan (Agustina Florentiana, 2015:118). Selain fasilitas medis yang mendukung, sistem akuntansi juga menjadi salah satu faktor terpenting dalam pencitraan sebuah klinik (Sri Subekti, 2015:36).

Untuk bisa lebih mengoptimalkan kualitas sumber daya manusia dengan membangun cara kerja yang lebih cepat dan akurat serta dapat meminimalisir kegiatan manual demi memaksimalkan pelayanan kepada pasien, maka diperlukan sistem informasi akuntansi dengan menggunakan software, khususnya yaitu software AxataPos. Selain itu juga didukung dengan manajemen yang handal sesuai dengan prinsip syariah yang tidak hanya mengandalkan teori, akal, keinginan, dan pengalaman manusia semata, tetapi juga harus melibatkan keselarasan hati dan takwa atas dasar iman yang benar kepada Allah SWT.

\section{Kerangka Konseptual}

\section{Akuntansi}

Akuntansi merupakan sebuah alat ukur, penjabaran, atau pemberian kepastian dari berbagai data-data informasi yang digunakan oleh manajer, investor, otoritas pajak, dan pembuat keputusan lain untuk menjadi sebuak tolak ukur pengambilan keputusan dalam pengalokasian sumber daya di dalam sebuah isntansi, perusahaan, organisasi, dan lembaga pemerintah (Lantip Susilowati, 2015:1).

Akuntansi menurut Suradi (2009:2) adalah sebuah seni pencatatan, pengukuran, pengelompokan, pengikhtisaran, serta mengidentifikasi sebuah kejadian ekonomi berupa transaksi-transaki financial yang terjadi pada periode tertentu di sebuah perusahaan.

Menurut Yulius (2011:10) mendefinisikan bahwa akuntansi merupakan sebuah proses pencatatan kemudian di identifikasi, dan melaporkan transaksi-transaksi yang berhubungan dengan kejadian ekonomi yang terjadi dalam suatu perusahaan dengan diakhiri dalam bentuk sebuah laporan keuangan

\section{Siklus Akuntansi}

Menurut Mulya siklus akuntansi merupakan proses pencatatan akuntansi mulai dari pengumpulan dokumen sampai penyusunan laporan keuangan (Haudri Mulya, 2013:7). 
Menurut Rudianto siklus akuntansi adalah proses kegiatan pengumpulan data, menganalisis, penyajian data, pengklasifikasian, pencatatan, meringkas, dan pelaporan atas transaksi perusahaan dalam bentuk informasi keuangan (Rudianto, 2012:15).

Menurut Suradi siklus akuntansi yaitu proses identifikasi dan analisis dari transaksi-transaksi kemudian diakhiri dengan penyajian laporan keuangan (Suradi, 2009:6).

Jadi siklus akuntansi adalah proses pencatatan dari aktivitas-aktivitas transaksi perusahaan yang kemudian di identifikasi hingga menyusun sebuah laporan keuangan.

\section{Akuntansi Manajemen}

Akuntansi Manajemen adalah sebuah sistem yang digunakan untuk pengolahan data-data financial maupun non financial yang kemudian menghasilkan output berupa informasi keuangan, dimana informasi tersebut digunakan oleh pihak internal suatu organisasi (Mulyadi, 2006:1).

Akuntansi Manajemen adalah sebuah penerapan serta pengembangan berbagai cara mengaanalisis, mencatatan, menginterprestasi dan mempresentasikan, dan membuat perhitungan biaya, yang digunakan dalam menjalankan fungsi kinerja manajeral, meliputi perencanaan, pengambilan keputusan, dan pengendalian (Riza Salman, 2016:2).

\section{Manajemen Bisnis Syariah}

Manajemen adalah sebuah proses perencanaan, pengorganisasian, pengoordinasian, dan pengontrolan sumber daya untuk mencapai sasaran (goal) secara efektif dan efisien (Riawan,
2010:4). Sedangkan Bisnis syariah adalah serangkaian aktivitas bisnis dalam berbagai bentuknya yang tidak dibatasi jumlah (kuantitas) kepemilikan hartanya (barang/jasa) termasuk profitnya, namun dibatasi dalam cara perolehan dan pendayagunaan hartanya (ada aturan halal dan haram) yang di landasi prinsip prinsip islam (Choirul, 2016:168).

Jadi manajemen bisnis syariah adalah sebuah proses aktivitas bisnis yang tidak sebatas mengajar dan mengatur urusan-urusan duniawi, namun juga mengajar dan mengatur urusanurusan ukhrowi, mulai dari perencanaan hingga pengelolaan sumber daya untuk mencapai tujuan tertentu yang landasi prinsip prisnip islam terkait moral dan etika sesuai dengan ajaran Al-Quran dan Hadist.

\section{Sistem Informasi Akuntansi}

Sistem informasi akuntansi adalah suatu sistem yang merupakan kombinasi antara manusia dengan fasilitas, teknologi, media, prosedur-prosedur dan pengendalian yang ditunjukan untuk mendapatkan jalur komunikasi penting, memperoses tipe transaksi rutin tertentu dalam sebuah organisasi (Saifudin dan Firda. 2017:126).

Diana dan Setiawati (2011:1) berpendapat bahwa sistem informasi akuntansi adalah sebuah sistem yang digunakan sebagai pengumpulan data kemudian diklasifikasikan sedemikian rupa yang akan menghasilkan sebuah informasi yang berkaitan dengan keuangan.

Sistem Informasi Akuntansi (SIA) adalah sebuah sistem yang bertugas untuk mengumpulkan serta mengolah data dari Implementasi Software Axata Pos | 137 
kegiatan suatu entitas kemudian memproses data tersebut menjadi sebuah informasi keuangan untuk memenuhi kebutuhan informasi mengenai laporan keuangan bagi pihak internal maupun ekternal entitas (Surabi, 2004:13).

Menurut Hall (2002:10) ada tiga subsistem utam dalam Sistem Informasi Akuntansi, yaitu :

1. Transaction Processing System yaitu sistem dalam pemrosesan transaksi.

2. General Ledger System yaitu sistem dalam pelaporan buku besar/keuangan.

3. Management Reporting System yaitu sistem dalam pelaporan manajemen.

\section{Tujuan Sistem Informasi Akuntansi}

Menurut Mulyadi (2010:19) ada empat tujuan umum dalam sistem informasi untuk penyusunannya, yaitu :

1. Sistem informasi dapat menyediakan sebuah informasi untuk kegiatan usaha baru bagi pengelolanya.

2. Sistem informasi dapat memperbaiki dalam ketepatan penyajian laporan maupun struktur informasinya agar lebih bermutu.

3. Sistem informasi dapat memperbaiki tingkat keandalan informasi akuntansi dan untuk menyediakan catatan lengkap mengenai pertanggungjawaban dan perlindungan kekayaan perusahaan.

4. Sistem informasi dapat digunakan untuk mengurangi biaya klerikal dalam penyelenggaraan catatan akuntansi.

\section{Elemen Sistem Informasi Akuntansi}

Dalam perusahaan tentunya terdapat beberapa siklus yang berkaitan dengan sistem informasi akuntansi antara lain (Yulianti dan Dian, 2020:1779).

1. Siklus Pendapatan (Revenue Cycle)

Dimana kejadian dalam siklus ini berkaitan dengan pendistribusia barang dan jasa ke entitas lain dan imbal baliknya berupa penerimaan kas yang terkait dengan pendistribusi tersebut.

2. Siklus Pengeluaran (expenditure cylce)

Dimana kejadian yang berkaitan dengan siklus ini yaitu dalam perolehan barang dan jasa dari entitas lain dan membayar kewajiban yang berkaitan atas perolehan barang dan jasa tersebut.

3. Siklus Produksi atau Konversi

Dalam siklus ini pemanfaatan sumber daya akan di transformasikan menjadi sebuah barang dan jasa.

4. Siklus Sumber daya manusia atau penggajian (human resources or payroll cycle)

Dimana siklus ini didalamnya terkait dengan pelatihan, memperkerjakan, memberi tunjangan, mengevaluasi, mempromosikan, dan memberhentikan karyawannya.

5. Siklus Pembiayaan (financing cycle)

Dimana kegiatan siklus ini berkait dengan pengumpulan dana dengan jual beli saham perusahaan kepada investor atau meminjam uang kepada lembaga keuangan serta membayar dividen dan bunga.

\section{Kesuksesan Sistem Informasi Akuntansi}

Kadek dan I Gusti mengemukakan bahwa sebuah keberhasilan yang telah tercapai dalam keefektifan sistem informasi akuntansi 
merupakan sebuah hal yang harus di apresiasi karena dapat menyajikan informasi secara akurat, tepat waktu, dan keamanan terjamin (Indah dan Suaryana, 2014). Adapun beberapa faktor penyebab keberhasilan dan kegagalan dalam implementasi sistem informasi yaitu :

1. Keterlibatan User dalam implementasi.

2. Dukungan dari pihak manajemen.

3. Kejelasan mengenai kebutuhan.

4. Perencanaan yang teapt dan matang guna mengahadapi resiko.

5. Kualitas manajemen agar dapat merealisasikan.

\section{Klinik}

Menurut Menteri Kesehatan Republik Indonesia No. 028/Menkes/PER/I/2011 pasal 1 ayat 1 klinik adalah sebuah fasilitas kesehatan yang menyelenggarakan pelayanan kesehatan per individual serta mengadakan pelayanan medis dasar dan/atau spesialistik, dengan dipimpin oleh satu tenaga medis yang beranggotakan beberapa jenis tenaga kesehatan.

Aktivitas klinik yaitu penyedia layanan kesehatan yang menyelenggarakan pelayanan kesehatan perorang yang menyediai pelayanan medis dasar dan/atau spesialistik, diselenggarakan oleh lebih dari satu jenis tenaga kesehatan (perawat dan atau bidan) dan dipimpin oleh seorang tenaga medis (dokter, dokter spesialis, dokter gigi atau dokter gigi spesialis) (Prima dan Tono, 2019)

\section{Sistem Informasi Klinik}

Sistem informasi klinik adalah sistem berbasis komputer yang menggunakan metode modern dengan mengganti cara lama yaitu catatan kertas, mengorganisir, mendesain, menyimpan, mengumpulkan, meniru, memeriksan ganda semua informasi medis, dan menyediakan pengiriman informasi penting klinis. Pada abad ke-21 sistem informasi klinis mengalami perkembangan dalam pelayanan kesehatannya. Sistem informasi klinik juga dapat diartikan sebagai kumpulan aplikasi teknologi informasi yang dapat menyediakan penyimpanan data informasi terpusat yang berhubungan dengan pelayanan kesehatan dan pelayanan pasien di lokasi-lokasi yang terdistribusi.

Dalam hal ini repositori menyediakan riwayat klinik pasien dan dokter mengenai kondisi pasien, pilihan pengobatan dan kesehatannya. Sistem informasi klinik juga disebut sebagai sistem berbasis komputer yang pada tujuan utamanya untuk mengumpulkan, menyimpan, dan memberikan semua informasi klinik yang penting sebagai pelayanan kepada pasien (Meilani, 2013:325).

Sistem informasi pada klinik sangat perdampak dalam peningkatan kualitas pelayanan kesehatan. Fungsi sistem informasi pada klinik yang paling banyak digunakan adalah pada penyediaan informasi khusus tehadap pasien dengan cara terorganisir, dan tepat waktu.

\section{Software Axata Technology}

Axata Technology adalah sebuah perusahaan berbasis teknologi yang membangun sebuah perangkat lunak berbasis mobile (aplikasi) dan desktop (software) dibidang akuntansi dan bergerak di skala perusahaan small and medium business enterprise atau disebut juga dengan UKM. Axata Technology memiliki tujuan yaitu Implementasi Software Axata Pos || 139 
untuk membantu dalam pengelolaan system keuangan berbasis teknologi. Adapun produk yang dihasilkan oleh perusahaan ini adalah software AxataPOS. Berikut keunggulan dari software AxataPOS yaitu:

1. Tampilan yang sederhana dari segi interface maupun dari segi penyajian laporan keuangan.

2. Terdapat berbagai macam menu untuk bertransaksi sehingga dapat memudahkan dalam pencatatan.

\section{METODE PENELITIAN}

Metode ini menggunakan pendekatan kualitatif, yaitu sampel yang digunakan adalah Klinik Sima Husada, dan jenis diskriptif karena teknik pengumpulan datanya yaitu observasi dengan menyimak serta mencatat informasi penting, kemudain wawancara yaitu dengan melaukan tanya jawab kepada manager dan admin. Selian itu juga mengumpulkan dokumentasi dengan cara melihat dokumendokumen seperti jurnal, catatan-catatan, dan buku-buku yang berkaitan dengan penelitian ini. Dimensi waktu yang digunakan adalah melibatkan urutan waktu. Risetnya hanya melibatkan satu objek (studi kasus). Historis, peneliti melakukan analisa berdasarkan datadata yang ada di klinik tersebut. Unit analisisnya merupakan Klinik Sima Husada

\section{PEMBAHASAN DAN HASIL}

\section{Tinjauan Klinik}

Klinik Kesehatan Sima Husada merupakan instansi yang menyediakan layananan kesehatan.
Beralamat di RT 04 RW 01, Jl. Raya Trisula, Krajan, Suruhwadang,Kademangan,Kabupaten Blitar dengan surat izin operasional Nomor: 440/23/409.104.4/ II/2018 dan NPWP: 70.217.816.1-653.000. Berdiri sejak tahun 2012 memulai dengan layanan terhadap pasien dan mengembankan diberbagai bidang layanan kesehatan. Kemudian meningkatkan di persediaan obat obatan dan alat kesehatan agar dapat memenuhi kebutuhan dari pasien.

\section{Tinjauan Kasus}

Klinik Sima Husada merupakan klinik yang bergerak di bidang kesehatan yang berfokus pada pasien rawat jalan dan rawat inap, selain itu juga ada Apotek untuk memenuhi kebutuhan obat-obatan bagi pasien klinik tersebut. Klinik kesehatan merupakan salah satu fasilitas pelayanan kesehatan yang dalam prosesnya membutuhkan sistem informasi yang cepat, tepat dan akurat serta memadai dalam meningkatkan pelayanannya bagi pasien. Hal ini menjadikan klinik kesehatan memiliki permasalahanpermasalahan.

Dalam hal ini klinik kesehatan ikut menentukan kecepatan informasi yang dibutuhkan oleh pemakai. Dalam pelayanannyapun juga mengandalkan informasi yang intensif. Informasi yang intensif dapat membantu klinik kesehatan dalam mengambil keputusan. Selain itu sistem informasi juga digunakan untuk memberikan pelayanan yang berguna untuk meningkatkan kepuasan pelanggan. Pada dasarnya klinik kesehatan memiliki dua jenis pasien, diantaranya pasien internal dan eksternal. Pasien internal yaitu bisa jadi dari pemilik klinik, manajer, 
perawat, admin, dan seluruh karyawan klinik kesehatan, dan pasien eksternalnya yaitu masyarakat diluar klinik secara luas (Daimatul dan Rahajo, 2014:13).

Permasalahan yang sering timbul dari penerimaan pasien sampai pasien kembali pulang yaitu dalam pencatatan transaksi yang sebagian masih manual. Sebenarnya klinik tersebut sudah menggunakan software namum hanya diguanakan sebagai transaksi penjualan obat obatan dan untuk mengecek harga obat saja. Hal ini dijelaskan oleh saudari Lucky selaku admin di Klinik Sima Husada:

"Jadi, Sebenarnya kami sudah menggunakan sofware, namun ada beberapa kendala dalam penggunaan tersebut yaitu terbatasnya dalam mengakses dan juga kami kesulitan dalam penggunaanya secara menyeleruh jadi kami juga menggunakan pencatatan manual di buku khusus."

Dengan adanya software akuntansi segala urusan yang berhubungan dengan transaksi akan lebih mudah, serta kebutuhan sistem informasi keuangan akan terpenuhi yaitu dalam bentuknya adalah laporan keuangan, penggunakan software akuntansi bagi entitas kecil (mikro) maupun besar (makro) ke depannya merupakan suatu kebutuhan yang harus digunakan.

Pencatatan kas keluar, kas masuk, rekam medis, penggajian, dan persediaan obat obatan seperti barang keluar, barang masuk, dan stock opname masih menggunakan sistem manual, yaitu ada catatan buku tersendiri sesuai dengan transaksi yang dilakukan. Hal ini dijelaskan oleh saudari Nerisa selaku apoteker di Klinik Sima Husada:

"Kami untuk masalah dalam pengendalian stock obat-obatan dan alat kesehatan masih menggunakan kartu stoksecara manual, meskipun hal tersebut memerlukan banyak waktu, dan terkadang mengalami kerepotan juga."

Maka diperlukannya tahapan-tahapan yang harus dibuat sebelum menyusun sebuah informasi keuangan, hal ini memakan waktu yang lama sehingga kurang efisien.

Dalam penyusunan laporan keuangan dibutuhkan suatu ketepatan, ketelitian, dan keakuratan agar laporan keuangan tersebut tidak diragukan keabsahannya oleh pihak eksternal maupun pihak internal, tentunya hal tesebut juga terdapat di Q.S An-Nisa Ayat 58:

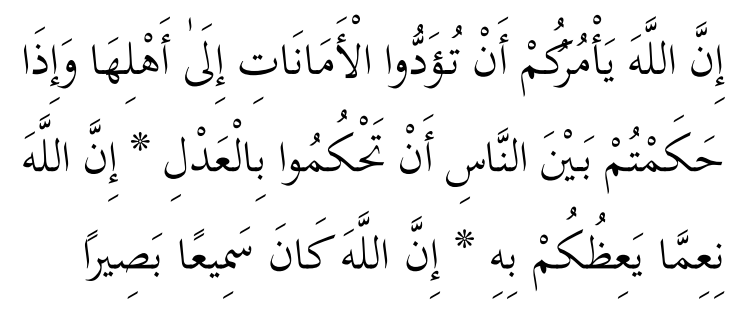

"Sesungguhnya Allah menyuruh kamu menyampaikan amanat kepada yang berhak menerimanya, dan (menyuruh kamu) apabila menetapkan hukum di antara manusia supaya kamu menetapkan dengan adil. Sesungguhnya Allah memberi pengajaran yang sebaik-baiknya kepadamu. Sesungguhnya Allah adalah Maha Mendengar lagi Maha Melihat".

Dari ayat tersebut dapat diambil tuntutan yaitu apabila mendapatkan suatu amanah harus dikerjakan dengan sungguh-sungguh dan dapat dipertanggungjawabkan serta jangan sampai terjadi kelalaian-kelalaian dalam menjalankan amanah tersebut.

Dan juga dalam hadist Ibnu Majah Nomor 2356, yaitu :

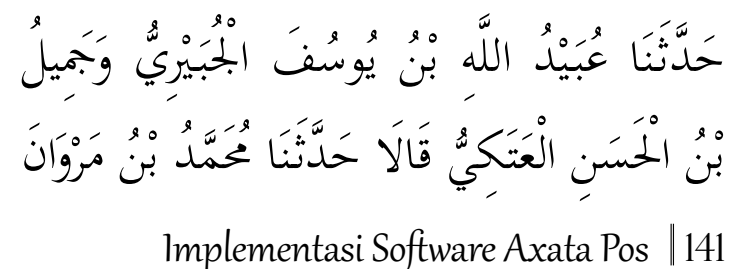
Implementasi Software Axata Pos | 141 


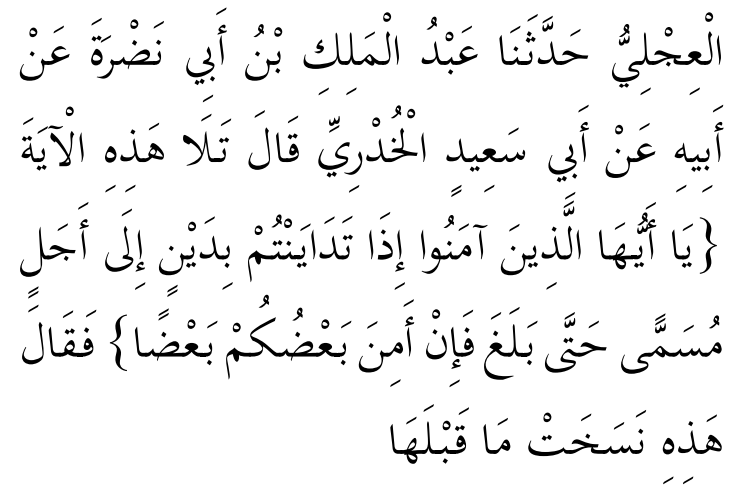

Telah menceritakan kepada kami [Ubaidullah bin Yusuf Al Jubairi] dan [Jamil bin Al Hasan Al Atiki] keduanya berkata; telah menceritakan kepada kami [Muhammad bin Marwan Al Ijli] berkata, telah menceritakan kepada kami [Abdul Malik bin An Nadlrah] dari [Bapaknya] dari [Abu Sa'id Al Khudri] ia berkata ketika dia membaca ayat ini: ' Wahai orang-orang yang beriman, apabila kalian berhutang piutang untuk waktu tertentu, hendaklah kalian menuliskannya, hingga ayat: Akan tetapi jika sebagian kalian percaya kepada sebagian yang lain', ia mengatakan, "Ayat ini menghapus ayat yang sebelumnya." Klinik sima husada dalam proses bisnisnya menerapkan sistem hutang piutang, dimana transaksi tersebut digunakan untuk pasien rawat inap. Sistem transaksi ini tidak mengandung unsur riba atau sistem bunga, justru dengan adanya sistem ini pasien merasa dimudahkan apabila pasien atau keluarga pasien belum bisa membayar tagihan di klinik tersebut, namun tetap ada kesepakatan dari kedua belah pihak.

\section{Tinjauan Dalam PersfektifManajemen Bisnis Syariah}

Dari hasil tinjauan dan pembahasan diatas, mengenai penggunaan sistem informasi akuntansi yang menggunakan program (software) yaitu diperbolehkan karena dapat memberikan manfaat bagai manajemen untuk mengelola kegaiatan bisnisnya yaitu menjadi lebih mudah, cepat, dan aman. Manajemen syariah juga membahas soal sistem. Dimana sistem ini disusun agar perilaku pelaku di dalamnya berjalan dengan baik, sehingga perilaku yang terkait dengan nilainilai keimanan dan ketauhidan akan terlampaui. Selain itu manajemen syariah juga mementingkan adanya struktur organisasi. Hal ini bisa dilihat pada surat Al-Mujadilah ayat 11:

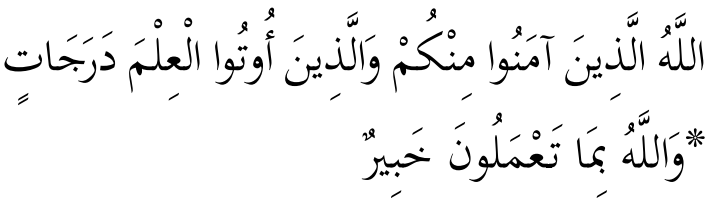

"Allah akan meninggikan orang-orang yang beriman di antaramu dan orang-orang yang diberi ilmu pengetahuan beberapa derajat. Dan Allah Maha Mengetahui apa yang kamu kerjakan. Dengan hal ini manusia berperan untuk mengelola yang ada dunia dengan tingkat kemampuan yang berbeda-beda".

Maka dari itu dalam menjalankan bisnis harus memiliki sistem yang jelas, sehingga jobdesk yang akan dikerjakan juga akan tertata. Sehingga bisnis klinik ini dalam jasa pelayanan terhadap masyarakat merupakan bentuk pemberian yang dapat meciptakan kemaslahatan khususunya dalam bidang kesehatan.

\section{PENUTUP}

\section{Kesimpulan}

Kesimpulan dari penelitian ini yang berjudul implementasi software AxataPOS dalam mememnuhi kebutuhan sistem informasi pada klinik kesehatan ditinjau dari prespektif manajemen bisnis syariah adalah pengolahan data transaksi akuntansi berbasis dekstop dalam hal ini menggunakan software akuntansi dapat mengurangi kesalahan-kesalahan yang terjadi contohnya mengurangi resiko kesalahan dalam pencatatan, implemetasi software akuntansi berbasis dekstop dapat membantu mempermudah

142 | Bagas Noval Pradipta, Lantip Susilowati, Husnul Haq 
dalam pengolahan data akuntansi dan penyajian laporan keuangan secara efektif dan efisien. Selain itu software ini memiliki fasilitas hak akses untuk keamanan bagi setiap pengguna yang ingin melakukan kecurangan dalam bentuk mengubah data maupun menghapus transaksi, dan AxataPOS dapat di terapkan pada bisnis apapun terutama bagi Usaha Mikro Kecil Menengah karena dapat dipelajari dengan mudah tanpa harus memiliki keahlian dalam bidang akuntansi. Dan dalam pandangan prespektif manajemen bisnis syariah diperbolehkan karena memberikan manfaat untuk mengurangi resiko kelalaian atau tanggung jawab di setiap bidangnya. Sehingga dapat memfokuskan pada jasa pelayanan terhadap masyarakat agar lebih baik kedepannya dan kemaslahatan masyarakat akan terus tercapai.

\section{Saran}

Diharapkan peneliti selanjutnya dapat menggali item-item informasi akuntansi yg terdapat dalam aplikasi akuntansi berbasis android baik untuk klinik kesehatan maupun bidang yang lain serta juga dapat menggali lebih optimal dengan memilih dan menganalisis aplikasi yg memiliki kreliteria informasi akuntansi lebih baik serta perlu mempertimbangkan sumber daya lainnya yang dimiliki oleh perusahaan yang dapat meningkatkan kinerja pegawai.

\section{DAFTAR KEPUSTAKAAN}

Amin, A. Riawan dan Tim PEBS FEUI. 2010. Menggagas Manajemen Syariah; Teori dan Praktik The Celestial Management, Edisi Pertama. Jakarta: Salemba Empat.
Departemen Agama R.I. 2012. Al-Quran dan Terjemahannya. Depok: Al-Fatih.

Diana \& Setiawati 2011. Sistem Informasi Akuntansi Edisi 1. Yogyakarta: Graha Ilmu.

Hall, A. James. 2002. Sistem Informasi Akuntansi. Buku Kedua Edisi kesatu. Terjemahan Amir Abadi Jusuf. Jakarta: Salemba Empat.

Khan, Muhammad Akram. 2008. Types of Business Organisation in an Islamic Economy, An introduction to Islamic Economics \& Finance, CERT Publication SDN. Kuala Lumpur: BHD.

Mulya, Haudri 2013. Memahami Akuntansi Dasar Pendekatan Teknis Siklus Akuntansi. Jakarta: Mitra Wacana Media.

Mulyadi. 2006. Akuntansi Manajemen, Edisi ke tiga. Jakarta: Salemba Empat.

Rudianto. 2012. Pengantar Akuntasni. Jakrta: Erlangga.

Suradi. 2009. Pengantar Akuntansi. Yogyakarta: Gaya Media.

Susilowati, Lantip. 2015. Mahir Akuntansi Perusahaan Jasa dan Dagang. Yogyakarta: KALIMEDIA.

Sutrabi, Tata. 2004. Sistem Informasi Akuntansi. Yogyakarta: ANDI.

Wahjono, Sentot Imam. 2010. Bisnis Modern. Yogyakarta: Graha Ilmu.

Yulius, Hendri. 2011. 7 Langkah Praktis Membuat PencatatanAkuntansi KeuanganUntukPerusahaan Jasa. Jakarta: PT Elex Media Komputindo.

Harsono, Alexander. 2018. Analisis Implementasi Sistem Informasi Manajemen Rumah SakitUmum Daerah (SIM-RSUD) Terintegrasi di Provinsi Kalimantan Barat. Jurnal Eksplora Informatika. Implementasi Software Axata Pos | 143 
Nena, Agustina Florentiana Du'a. 2015. Analisa Sistem Informasi Akuntansi Dalam Meningkatkan Pengendalian Internal Atas Pendapatan Di Rumah Sakit HermanaLembean. Jurnal Emba Vo. 3 No. 6.

Yulliarto, Rahajo, dkk. 2014. Rancang Bangun Sistem Informasi Klinik Dengan Layanan Online Report Menggunakan Pascal IDE dan MySQL Pada Klinik Mitra Anda. Jurnal Rekayasa dan Teknologi Elektro.

Maria, Dana Ika dan Rita Indah Mustikowati. 2016. Analisis Sistem Informasi Akuntansi (Sia) Pendapatan Rawat Inap Kamar Vip Rsud Kota Lawang. Journal Riset Mahasiswa Akuntansi (Jrma).

Munggaran, Diky Fajar. 2014. Perancangan Sistem Informasi Klinik Gigi Drg. Taofik Hidayat. Elib Unikom.

Adikrisna, Diyas. 2014. Penerapan Aplikasi Sistem Stok Barang Dan Keuangan Pada Apotek Sana Farma Semarang. Ejournal Stekom Semarang.

Ompusunggu, Hermaya. 2018. Analisis Sistem Informasi Akuntansi Penerimaan Dan Pengeluaran Kas Pada Rsia "Kasih Sayang Ibubatam" Jursima Https://Ejournal. Stmikgici.Ac.Id/ Jurnal Sistem Informasi Dan Manajemen Stmik Gici Issn 2338-1523 E-Issn 2541-576x Volume 6 No. 2.

Huda, Choirul. MODEL PENGELOLAAN BISNIS SYARI'AH: Studi Kasus Lembaga Pengembangan Usaha Yayasan Badan Wakaf Sultan Agung Semarang. Jurnal Penelitian
Sosial Keagamaan, Vol. 24 No. 1, Mei 2016, 165-190.

Pasaribu,Johni S dan Johnson Sihombing. 2017. Perancangan Sistem Informasi Rekam Medis Pasien Rawat Jalan Berbasis Web Diklinik Sehat Margasari Bandung. Jurnal Ilmiah Teknologi Informasi Terapan Vol. 3 No. 3.

Ratnaningsih, Kadek Indah dan I Gusti Ngurah Agung Suaryana. 2014. Pengaruh Kecanggihan Teknologi Informasi, Partisipasi Manajemen, Dan Pengetahuan Manajer Akuntansi Pada Efektivitas Sistem Informasi Akuntansi. E-Journal Akuntansi Universitas Udayana. Bali. Mamahit, Patricia, dkk. 2014. Evaluasi Sistem Informasi Akuntansi Penerimaan Dan Pengeluaran Kas Rawat Inap Pada Rsup. Prof. Dr. R.D. Kandou Manado. Jurnal Emba Vol.2 No.4.

Siregar, Masita Ichwani dan R. Fenny Syafariani. 2019. Pengembangan Sistem Informasi Kepegawaian Berbasisn Web Pada Klinik Tanaya. Elibrary Unikom.

Menteri Kesehatan Republik Indonesia No. 028/ Menkes/PER/I/2011 pasal 1 ayat 1

Sidiq, Muhammad Fajar dan Novrini Hasti. 2019. Sistem Informasi Rekam Medis Di Klinik Sakura. Elibrary Unikom.

Nikmah dan Masriatun. 2013. Penerapan Sistem Informatika Akuntansi Pada Klinik Daqu Sehat Malang. Etheses UIN Malang.

Epanop, Putra Prima dan Tono Hartono. 2019. Sistem Informasi Pelayanan Kesehatan Gigi Diklinik Gigi Almeera Berbasis Web. Elibrary Unikom. 
VOLUME 4, NOMOR 2, DESEMBER 2020

Salim, Rin Rin Meilani. 2013. Pengembangan Sistem Informasi Klinik Berbasis Web. Seminar Nasional Sistem Informasi Indonesia.

Saifudin, Firda Pri Ardani. 2017. Sistem Informasi Akuntansi Penerimaan Dan Pengeluaran Kas Dalam Meningkatkan Pengendalian Internal Atas Pendapatan Pada Rsup Dr. Kariadi Semarang. Jurnal Riset Akutansi Keuangan Vol. 2 No. 2.

Salman, Kautsar Riza dan Mochammad Farid. 2016. AKUNTANSI MANAJEMEN "Alat Pengukuran dan Pengambilan Keputusan Manajeral". Jakarta : Indeks.

Subekti, Sri dan Rosi Susiyanti. 2015. Aplikasi Sistem Informasi Administrasi Klinik (Studi Kasus: Klinik Jakarta Skin Center). Jurnal Sisfotek Global Vol 5 No. 2.
Permana, Thomas Andika. 2017.Analisis Penerapan Sistem Informasi Akuntansi Penerimaan Kas (Studi Kasus di Klinik Adhiwarga PKBI DIY). Skripsi Universitas Sanata Dharma.

Wahyudiyanto. 2017. Implementasi Sistem Informasi Manajemen Pada Pt. Erha Clinic Indonesia. Ejournal Mercu Buana.

Effendi, Yulianti. dkk. 2020. Analisis Sistem Informasi Akuntansi Pada Perusahaan StartUp (Studi Kasus Pada Pt Kuliner Global Sejati). Ejournal Upn Veteran Jakarta.

Wawancara dengan Lucky, tanggal 4 Oktober 2019 di klinik Sima Husada Suruhwadang Kabupaten Blitar.

Wawancara dengan Nerisa, tanggal 4 Oktober 2019 di klinik Sima Husada Suruhwadang Kabupaten Blitar. 